\title{
The sensitivity and specificity of the toe brachial index in detecting peripheral arterial disease
}

\author{
Peta Craike ${ }^{1 *}$, Vivienne Chuter ${ }^{1}$, Alan Bray ${ }^{2}$, Ruth Keech ${ }^{2}$ Richard Rownsley², Angela Carruthers ${ }^{2}$ \\ From Australasian Podiatry Council Conference 2013 \\ Sydney, Australia. 2-5 June 2013
}

\section{Background}

Peripheral arterial disease (PAD) is reported to affect up to $12 \%$ of the adult population and has significant health ramifications. PAD is associated with delayed wound healing and amputation. Podiatric vascular assessment plays an important part of identifying PAD. Traditionally, ankle brachial indices (ABI) have been used as a screening tool for non-invasive assessment of PAD however recent evidence has suggested that in certain populations there may be a decrease in the ABI's sensitivity and specificity. The toe brachial index (TBI) has been suggested as potentially a more reliable indicator of the presence of PAD however, there is limited evidence currently on the validity of the TBI.

\section{Methods}

Participants were recruited from a Private Vascular Clinic, and a Community Health Centre Podiatry Service. ABI and TBI's were performed on all participants. Colour duplex ultrasound (CDU) was used to determine the presence or absence of PAD. Diagnostic accuracy of ABI and TBI results were then determined through comparison with CDU scans.

\section{Results}

56 participants were recruited to this study (M:40 F:16). The results of this study demonstrated that sensitivity for the presence of PAD was reduced in the ABI compared to the TBI measurements (47\% and $95 \%$ respectively). The ABI measurement had higher specificity for detecting PAD than the TBI measurement $(79 \%$ and $91 \%$ respectively).

\footnotetext{
* Correspondence: Peta.Craike@newcastle.edu.au

${ }^{1}$ School of Health Sciences, Faculty of Health, University of Newcastle, Australia

Full list of author information is available at the end of the article
}

\section{Conclusion}

The results of this study indicate that the TBI measurement is more likely to detect the presence of significant PAD as diagnosed by CDU across a mixed population.

\section{Author details}

'School of Health Sciences, Faculty of Health, University of Newcastle, Australia. ${ }^{2}$ Vascular Health Centre, Gateshead, Australia.

Published: 31 May 2013

doi:10.1186/1757-1146-6-S1-P3

Cite this article as: Craike et al.: The sensitivity and specificity of the toe brachial index in detecting peripheral arterial disease. Journal of Foot and Ankle Research 2013 6(Suppl 1):P3.
Submit your next manuscript to BioMed Central and take full advantage of:

- Convenient online submission

- Thorough peer review

- No space constraints or color figure charges

- Immediate publication on acceptance

- Inclusion in PubMed, CAS, Scopus and Google Scholar

- Research which is freely available for redistribution
() Biomed Central

\section{Biomed Central}

(c) 2013 Craike et al; licensee BioMed Central Ltd. This is an Open Access article distributed under the terms of the Creative Commons Attribution License (http://creativecommons.org/licenses/by/2.0), which permits unrestricted use, distribution, and reproduction in any medium, provided the original work is properly cited. 